Quim. Nova, Vol. 34, No. 9, 1550-1555, 2011

\title{
CHEMICAL COMPOSITION AND ANTIBACTERIAL ACTIVITY OF ESSENTIAL OILS FROM VERBENACEAE SPECIES: ALTERNATIVE SOURCES OF (E)-CARYOPHYLLENE AND GERMACRENE-D
}

\author{
Ricardo M. Montanari, Luiz C. A. Barbosa,* Antonio J. Demuner e Cleber J. Silva \\ Departamento de Química, Universidade Federal de Viçosa, Av. PH Rolfs, s/n, 36570-000 Viçosa - MG, Brasil \\ Larissa S. Carvalho e Nélio J. Andrade \\ Departamento de Tecnologia de Alimentos, Universidade Federal de Viçosa, Av. PH Rolfs, s/n, 36570-000 Viçosa - MG, Brasil
}

Recebido em 7/1/11; aceito em 4/5/11; publicado na web em 29/6/11

\begin{abstract}
Volatile oils from the leaves of Verbenaceae species Aloysia virgata, Lantana camara, Lantana trifolia, Lantana montevidensis, Lippia brasiliensis and Lippia sericea were investigated for its chemical composition and antibacterial activity. The volatile oils were characterized by a high content of sesquiterpenes of which (E)-caryophyllene (10-35\%), germacrene-D (5-46\%) and bicyclogermacrene (7-17\%) were the major components for all studied species. For the flowers, a higher concentration of monoterpenes was observed for the species $L$. camara, L. trifolia and L. brasiliensis. These compounds probably act as attractive to specific pollinators. The volatile oils from $A$. virgata was the most active, exhibiting moderate antimicrobial activity against the bacteria Staphylococcus aureus, Bacillus cereus and Escherichia coli.
\end{abstract}

Keywords: Lippia spp; Aloysia virgata; Lantana spp.

\section{INTRODUCTION}

The Verbenaceae comprises several species with medicinal and ornamental uses, especially those of the genera Aloysia Palau, Lantana L., Lippia L. and Stachytarpheta Vahl. This family occurs in virtually all lands ecosystems, and it is one of the five most important dicotyledons families of the Brazilian altitude grassland. ${ }^{1}$ The family includes 2600 species grouped into 100 genera with pantropical distribution.

Cavalcanti et $a l .{ }^{2}$ described the acaricidal activity for the Lippia sidoides Cham volatile oils and its major compounds (thymol, carvacrol and (E)-caryophyllene). The volatile oils from $L$. multiflora Moldenke was more active than the one from $L$. chevalieri Moldenke against Gram-negative and Gram-positive bacteria. ${ }^{3}$ The infusion from leaves of L. javanica (Burm f.) Spreng is commonly used as coughs suppressant and decongestant and its essential oil has been shown to possess antimicrobial activity. ${ }^{4}$ The non-polar extracts of $L$. adoensis Hochst had an inhibitory effect on growth of Staphylococcus aureus, Escherichia coli, Pseudomonas aeruginosa and the fungus Trichophyton mentagrophytes. ${ }^{5}$

The essential oils from Aloysia triphylla Royle and Lippia alba (Mill.) N.E. Br has been shown to present antifungal activity against Candida albicans. ${ }^{6}$ Essential oils from Aloysia virgata collected in $\mathrm{Cuba}^{7}$ and Argentina ${ }^{8}$ were rich in sesquiterpenes such $(E)$-caryophyllene (16-19\%), germacrene-D (16-27\%) and bicyclogermacrene (18-29\%). The chemical composition and the antibacterial activity were also demonstrated by the volatile oils from Lantana camara L. ${ }^{9}$ and Lantana montevidensis. ${ }^{10}$ However, the geographic origin and genetic variability of the plants can influence the chemical composition. Therefore, studies on the occurrence and chemical composition of these plants in different regions are needed.

It is known that the occurrence of secondary metabolites with similar biological activities can be expected in phylogenetically

*e-mail: 1cab@ufv.br related plants, ${ }^{11}$ which may contribute to the implementation of more rational approaches for the search of new substances with potential economic interest. This hypothesis supports the search for antimicrobial substances among Verbenaceae species. In addition, the Verbenaceae family is widely spread in Brazil. The Cadeia do Espinhaço region, in Minas Gerais and Goiás states, represent one of the major centers of diversity of Lippia genera. Most species from this genus at this region are at risk of extinction due to the vulnerability of this area and there are few phytochemical studies to date on such plants. ${ }^{12}$

Therefore, in line with our studies on the biological activities and composition of volatile oils from several plant species,${ }^{13}$ this work describes the chemical composition of essential oils from Aloysia virgata (Ruiz \& Pav.) Pers., Lippia brasiliensis (Link) T. Silva, Lippia sericea Sham., Lantana camara L., Lantana trifolia L. and Lantana montevidensis (Spreng.) Briq. and the antibacterial activity of oil from five of these species. Also, we report on the seasonal variation of volatiles from Lippia brasiliensis since, to the best of our knowledge, its chemical composition has not been previously reported.

\section{EXPERIMENTAL}

\section{Plant material}

Aerial parts of the following species were collected in Atlantic Rainforest fragments of different cities of the Minas Gerais state, Brazil, the voucher specimens have been deposited in the VIC Herbarium of the Departamento de Biologia Vegetal, Universidade Federal de Viçosa (UFV): Aloysia virgata (Ruiz \& Pav.) Pers., Viçosa, VIC 7633; Lippia brasiliensis (Link) T. Silva, Viçosa, VIC 31852; Lippia sericea, Ouro Branco, VIC 21365; Lantana camara L., Tocantins, VIC 30159; Lantana trifolia L., Tocantins, VIC 21550; and Lantana montevidensis (Spreng.) Briq., Viçosa, VIC 21551. The samples were handling along March 2008 to January 2009. 


\section{Essential oil extraction}

Leaves and flowers were collected separately, in triplicate and completely randomized way among individuals of the studied populations. Each sample (100 g) was chopped and subjected to three hours hydrodistillation in a Clevenger-type apparatus. The resulting oils were separated, weighed and their yields calculated with respect to dry matter mass. Oils were stored under nitrogen atmosphere and maintained at $-4{ }^{\circ} \mathrm{C}$, until they were analyzed by gas chromatography or used in the bioassays.

\section{Gas chromatography (GC)}

GC analyses were carried out with a GC-17A Series instrument (Shimadzu, Japan) equipped with a flame ionization detector (FID). Chromatographic conditions were as follows: fused silica capillary column (30 m x $0.22 \mathrm{~mm})$ with a DB-5 bonded phase $(0.25 \mu \mathrm{m}$ film thickness); carrier gas, $\mathrm{N}_{2}$ at a flow rate of $1.8 \mathrm{~mL} \mathrm{~min}^{-1}$; injector temperature $220^{\circ} \mathrm{C}$, detector temperature $240{ }^{\circ} \mathrm{C}$; column temperature was programmed to start at $55^{\circ} \mathrm{C}$ (isothermal for $2 \mathrm{~min}$ ), with an increase of $3{ }^{\circ} \mathrm{C} \mathrm{min}^{-1}$, to $240{ }^{\circ} \mathrm{C}$, isothermal at $240{ }^{\circ} \mathrm{C}$ for $15 \mathrm{~min}$; injection of $1.0 \mathrm{~mL}(1 \% \mathrm{w} / \mathrm{v}$ in dichloromethane); split ratio $1: 10$; column pressure of $115 \mathrm{kPa}$.

The analyses were carried out in triplicate and the amount of each compound was expressed as a relative percentage of the total area of the chromatograms.

\section{Gas chromatography-mass spectrometry (GC-MS)}

The GC-MS unit (model GCMS-QP5050A, from Shimadzu, Japan) was equipped with a DB-5 fused silica column (30 $\mathrm{m}$ x $0.22 \mathrm{~mm}$ i.d., film thickness $0.25 \mu \mathrm{m}$ ) and interfaced with an ion trap detector. Transfer line temperature, $240{ }^{\circ} \mathrm{C}$; ion trap temperature, $220^{\circ} \mathrm{C}$; carrier gas, $\mathrm{He}$ at a flow rate of $1.8 \mathrm{~mL} \mathrm{~min}^{-1}$; injector temperature $220{ }^{\circ} \mathrm{C}$, detector temperature $240{ }^{\circ} \mathrm{C}$; column temperature was programmed to start at $55^{\circ} \mathrm{C}$ (isothermal for $2 \mathrm{~min}$ ), with an increase of $3{ }^{\circ} \mathrm{C} \mathrm{min}^{-1}$, to $240{ }^{\circ} \mathrm{C}$, isothermal at $240{ }^{\circ} \mathrm{C}$ for $15 \mathrm{~min}$; injection of $1.0 \mu \mathrm{L}(1 \% \mathrm{w} / \mathrm{v}$ in dichloromethane); split ratio $1: 10$; column pressure of $100 \mathrm{kPa}$; ionization energy, $70 \mathrm{eV}$; scan range, 29-450 u; scan time, $1 \mathrm{~s}$. The identity of each component was assigned by comparison of their retention indexes (RRI), relative to a standard alkane series $\left(\mathrm{C}_{9}-\mathrm{C}_{27}\right)$ and also by comparison of its mass spectrum with either reference data from the equipment database (Wiley 330 000) and from the literature. ${ }^{14}$

\section{Biological assays}

Bacterial strains were obtained from the collections of the Department of Microbiology, Federal University of Viçosa, Viçosa, Minas Gerais state, Brazil. Microorganisms used were Gram-positive Staphylococcus aureus (ATCC 25923) and Bacillus cereus, Ribotype 1 222-173-S4 isolated from post-pasteurization equipment surfaces; ${ }^{15}$ and Gram-negative Escherichia coli (ATCC 11229).

The agar disc diffusion method was employed to determine the antimicrobial activity of the essential oils, as previously described. ${ }^{16}$ Briefly, a suspension of the tested microorganism $\left(2 \times 10^{8} \mathrm{CFU} \mathrm{mL} \mathrm{mL}^{-1}\right)$ was spread on Petri plates with Mueller Hinton agar. Filter paper discs (6 mm diameter) were individually impregnated with $5 \mu \mathrm{L}$ of the essential oils and placed on the inoculated plates. The plates were incubated for $48 \mathrm{~h}$ at $37^{\circ} \mathrm{C}$ in the cases of $S$. aureus and E. coli and at $32{ }^{\circ} \mathrm{C}$ for $\mathrm{B}$. cereus. The diameters of the inhibition zones were measured using a paquimeter and expressed in millimeters. The antibiotic chloramphenicol $(30 \mu \mathrm{g})$ and sterile water were included in each experiment as positive and negative controls. Each test was performed in triplicates and repeated three times. The results were analyzed by ANOVA and Scott-Knott's multiple-range tests at $\mathrm{P} \leq 0.05$ by using the software GENES (Genetics and Statistical Analysis. Version 2007.0.0 - Federal University of Viçosa, Viçosa - MG, Brazil).

\section{Determinations of minimum inhibitory concentration (MIC)}

A broth microdilution method was used to determine the minimum inhibitory concentration (MIC). ${ }^{17}$ A serial doubling dilution of each essential oil was prepared in a 96-well microtiter plate over the range $0.0156-2 \%$. The broth was supplemented with Tween 80 (Merck, Germany) at a concentration of $0.5 \%(\mathrm{v} / \mathrm{v})$ in order to enhance essential oils solubility. Overnight broth cultures of each strain were prepared in Brain Heart Infusion Broth (Himedia) and the final concentration in each well was adjusted to $2 \times 10^{5} \mathrm{CFU} / \mathrm{mL}$ following inoculation. The concentration of each inoculum was confirmed by viable count on Plate Count Agar (Himedia). Positive and negative growth controls were included in every test. The plates was incubated aerobically at $30^{\circ} \mathrm{C}$ (Gram-negative) or $37^{\circ} \mathrm{C}$ (Gram-positive) according to strain. The MIC is defined as the lowest concentration of the essential oil at which the microorganism tested does not demonstrate visible growth. The bacteria growth was indicated by the turbidity, accessed in a spectrophotometer at $625 \mathrm{~nm}$.

\section{RESULTS AND DISCUSSION}

\section{Chemical composition}

The yields of volatile oils from the leaves and flowers ranged from 0.04 to $0.7 \%$ depending on the species and the part of the plant analyzed (Table 1). The highest yields were found in the flowers from L. brasiliensis $(0.7 \%)$, L. camara $(0.6 \%)$ and L. trifolia $(0.7 \%)$. For the leaves, the lowest yields were in the species Lippia sericea $(0.04 \%)$.

The major constituents identified from the volatile oils of the species investigated are listed in Table 1.

It was found that essential oils from Lippia species contains greater amount of $(E)$-caryophyllene than germacrene-D, whereas the oils from Aloysia and Lantana species have more germacrene-D than $(E)$-caryophyllene.

Sesquiterpene skeletal diversity arises from the action of a number of sesquiterpene synthases enzymes. ${ }^{18}$ The reaction mechanism of all sesquiterpene synthases starts with the ionization of farnesyl diphosphate. The resulting carbocation can undergoes a range of cyclizations. The 11,1-closure yields the 11-membered ring humulyl cation. Then, deprotonation followed by cyclobutane ring formation leads to (E)-caryophyllene production. Otherwise, the 10,1-closure originates the germacrenyl cation, which can be converted to germacrene-D. Thus, the precursors flow toward one of these constituents can reduce the amounts of the other. ${ }^{19}$

Lantana camara is the most widespread species of Lantana genus. The volatiles oils of some varieties of $L$. camara have been studied and they differ in composition according to geographic origin of the plants. ${ }^{20}$ In spite of geographic differences, the major constituents observed for some samples obtained from different locations in Brazil were limonene $(16.5 \%), \alpha$-phellandrene $(16.4 \%)$, germacrene-D $(13.2 \%),(E)$-caryophyllene $(10.8 \%)$ and sabinene $(8.9 \%) .^{21}$

The species $L$. trifolia is a small shrub that occurs in all regions of Brazil and is used in folk medicine in the form of infusions and syrups for the treatment of respiratory disorders and as sedative. Muhayimana et al. $^{22}$ observed that $(E)$-caryophyllene and germacrene-D were also the major volatile oil constituents in this plant.

In general, for all studied species, the content of monoterpenes was higher in oils extracted from flowers compared with the oils 
Table 1. Constituents and yields of essential oils (\%) from species Aloysia virgata (ALVG), Lippia sericea (LPSR), Lantana camara (LTCM), L. trifolia (LTTF) and L. montevidensis (LTMT)

\begin{tabular}{|c|c|c|c|c|c|c|c|c|}
\hline \multirow[t]{2}{*}{ Constituents } & \multirow[t]{2}{*}{$\mathrm{IR}^{\mathrm{a}}$} & \multirow{2}{*}{$\begin{array}{l}\text { ALVG } \\
\text { Leaves } \\
\end{array}$} & \multirow{2}{*}{$\begin{array}{c}\text { LPSR } \\
\text { Leaves } \\
\end{array}$} & \multicolumn{2}{|c|}{ LTCM } & \multicolumn{2}{|c|}{ LTTF } & \multirow{2}{*}{$\begin{array}{l}\text { LTMT } \\
\text { Leaves } \\
\end{array}$} \\
\hline & & & & Leaves & Flowers & Leaves & Flowers & \\
\hline Hydrocarbon Monoterpenes & & 8.8 & 0.5 & - & 17.8 & - & 12.3 & - \\
\hline$\alpha$-Thujene & 931 & - & - & - & $0.5 \pm 0.1$ & - & - & - \\
\hline$\alpha$-Pinene & 939 & $1.2 \pm 0.0$ & - & - & $1.5 \pm 0.2$ & - & - & - \\
\hline Sabinene & 976 & $0.4 \pm 0.1$ & - & - & $2.2 \pm 0.3$ & - & $7.9 \pm 0.6$ & - \\
\hline$\beta$-Pinene & 980 & - & - & - & $1.4 \pm 0.2$ & - & $0.2 \pm 0.0$ & - \\
\hline p-Cymene & 1026 & - & - & - & $0.3 \pm 0.0$ & - & - & - \\
\hline Limonene & 1031 & $1.4 \pm 0.1$ & - & - & $7.8 \pm 0.4$ & - & $2.8 \pm 0.2$ & - \\
\hline$(Z)-\beta$-Ocymene & 1040 & $0.8 \pm 0.2$ & - & - & - & - & $1.4 \pm 0.1$ & - \\
\hline$(E)-\beta$-Ocymene & 1050 & $5.0 \pm 0.5$ & $0.5 \pm 0.2$ & - & $0.9 \pm 0.1$ & - & - & - \\
\hline$\gamma$-Terpinene & 1062 & - & - & - & $3.2 \pm 0.2$ & - & - & - \\
\hline Oxygenated Monoterpenes & & - & 2.9 & - & 1.8 & - & 1.4 & - \\
\hline Linalol & 1098 & - & $1.4 \pm 0.3$ & - & $1.8 \pm 0.1$ & - & $0.8 \pm 0.0$ & - \\
\hline Terpinen-4-ol & 1177 & - & - & - & - & - & $0.6 \pm 0.1$ & - \\
\hline Piperitone & 1252 & - & $0.4 \pm 0.2$ & - & - & - & - & - \\
\hline Bornyl acetate & 1285 & - & $1.1 \pm 0.3$ & - & - & - & - & - \\
\hline Hydrocarbon Sesquiterpenes & & 81.4 & 48.3 & 91.0 & 73.0 & 64.3 & 79.9 & 80.7 \\
\hline$\delta$-Elemene & 1339 & $0.7 \pm 0.1$ & $0.6 \pm 0.1$ & $1.5 \pm 0.2$ & $1.8 \pm 0.2$ & - & - & - \\
\hline$\alpha$-Cubebene & 1351 & - & $0.2 \pm 0.1$ & - & - & - & - & - \\
\hline$\alpha$-Copaene & 1376 & $0.4 \pm 0.0$ & $0.6 \pm 0.2$ & $3.3 \pm 0.1$ & $4.7 \pm 0.3$ & $3.8 \pm 0.3$ & $3.0 \pm 0.2$ & $1.3 \pm 0.2$ \\
\hline$\beta$-Bourbonene & 1384 & - & - & $1.1 \pm 0.2$ & $0.3 \pm 0.1$ & - & - & $0.8 \pm 0.1$ \\
\hline$\beta$-Cubebene & 1390 & - & $0.3 \pm 0.2$ & - & - & - & - & - \\
\hline$\beta$-Elemene & 1391 & $1.8 \pm 0.1$ & $1.3 \pm 0.6$ & - & $0.8 \pm 0.2$ & $1.4 \pm 0.1$ & $2.9 \pm 0.2$ & $1.8 \pm 0.3$ \\
\hline$\alpha$-Gurjunene & 1409 & - & - & - & - & - & - & - \\
\hline (E)-Caryophyllene & 1418 & $8.9 \pm 0.8$ & $16.8 \pm 1.2$ & $17.0 \pm 1.1$ & $13.6 \pm 0.9$ & $10.2 \pm 1.2$ & $16.1 \pm 0.7$ & $9.2 \pm 1.2$ \\
\hline Aromadendrene & 1439 & - & $1.0 \pm 0.5$ & - & - & - & - & - \\
\hline$\alpha$-Guaiene & 1439 & - & $1.5 \pm 0.3$ & - & - & - & - & - \\
\hline$\alpha$-Humulene & 1454 & $1.6 \pm 0.1$ & - & $1.7 \pm 0.2$ & $1.6 \pm 0.2$ & - & $1.5 \pm 0.1$ & $1.3 \pm 0.1$ \\
\hline (E)- $\beta$-Farnesene & 1458 & - & - & - & $0.5 \pm 0.1$ & - & - & - \\
\hline Alloaromadendrene & 1461 & $0.2 \pm 0.1$ & - & $2.3 \pm 0.3$ & $1.9 \pm 0.2$ & $2.4 \pm 0.2$ & $1.9 \pm 0.2$ & $2.1 \pm 0.5$ \\
\hline Germacrene-D & 1480 & $46.3 \pm 1.1$ & $4.6 \pm 0.7$ & $46.1 \pm 1.4$ & $32.4 \pm 1.6$ & $29.5 \pm 1.4$ & $38.1 \pm 1.2$ & $42.7 \pm 1.2$ \\
\hline$\beta$-Selinene & 1485 & - & $0.8 \pm 0.4$ & - & - & - & - & - \\
\hline Valecene & 1491 & - & - & - & - & - & - & $0.7 \pm 0.1$ \\
\hline Bicyclogermacrene & 1494 & $17.4 \pm 1.0$ & $7.1 \pm 1.5$ & $8.5 \pm 0.7$ & $5.8 \pm 0.6$ & $9.1 \pm 0.3$ & $11.0 \pm 0.6$ & $16.1 \pm 0.9$ \\
\hline$\alpha$-Muurolene & 1499 & - & $0.5 \pm 0.3$ & - & $0.4 \pm 0.1$ & $2.5 \pm 0.1$ & $1.0 \pm 0.1$ & $1.0 \pm 0.2$ \\
\hline Germacrene-A & 1503 & $1.1 \pm 0.3$ & $2.9 \pm 0.6$ & - & $0.5 \pm 0.2$ & $1.8 \pm 0.1$ & $2.5 \pm 0.2$ & $1.7 \pm 0.3$ \\
\hline$\gamma$-Cadinene & 1513 & $0.5 \pm 0.1$ & $0.4 \pm 0.2$ & $1.7 \pm 0.2$ & $0.4 \pm 0.0$ & - & - & - \\
\hline (Z)-Calamenene & 1521 & - & - & - & - & - & - & - \\
\hline$\delta$-Cadinene & 1524 & $1.3 \pm 0.3$ & $2.8 \pm 0.9$ & $3.6 \pm 0.3$ & $3.3 \pm 0.1$ & $3.6 \pm 0.2$ & $1.9 \pm 0.1$ & $2.0 \pm 0.2$ \\
\hline Germacrene-B & 1556 & $1.2 \pm 0.2$ & $6.9 \pm 1.1$ & $4.2 \pm 0.5$ & $5.0 \pm 0.4$ & - & - & - \\
\hline Oxygenated Sesquiterpenes & & 6.8 & 32.9 & 1.5 & 1.3 & 8.7 & 2.8 & 14.3 \\
\hline (E)- $\beta$-Damascenone & 1380 & - & $0.3 \pm 0.1$ & - & - & - & - & - \\
\hline Geranyl-acetone & 1453 & - & $5.0 \pm 1.3$ & - & - & - & - & - \\
\hline Elemol & 1549 & $0.7 \pm 0.1$ & - & - & - & - & - & - \\
\hline (E)-Nerolidol & 1564 & - & $0.4 \pm 0.2$ & - & - & $5.3 \pm 0.4$ & - & $6.1 \pm 0.5$ \\
\hline Germacrene-D-4-ol & 1574 & $1.2 \pm 0.2$ & - & $0.7 \pm 0.1$ & $0.5 \pm 0.1$ & - & $0.6 \pm 0.1$ & - \\
\hline Spathulenol & 1576 & - & $6.4 \pm 0.7$ & - & - & - & $0.9 \pm 0.0$ & $3.2 \pm 0.4$ \\
\hline Caryophyllene oxide & 1581 & - & $8.1 \pm 0.7$ & $0.8 \pm 0.1$ & - & $2.3 \pm 0.1$ & - & $1.7 \pm 0.3$ \\
\hline Viridiflorol & 1590 & $4.2 \pm 0.3$ & $1.4 \pm 0.2$ & - & - & - & - & - \\
\hline$\alpha$-Muurolol & 1645 & - & $5.3 \pm 0.5$ & - & - & - & - & $1.8 \pm 0.1$ \\
\hline$\alpha$-Cadinol & 1653 & $0.7 \pm 0.1$ & $2.9 \pm 0.9$ & - & $0.8 \pm 0.2$ & $1.1 \pm 0.0$ & $1.3 \pm 0.3$ & $1.5 \pm 0.1$ \\
\hline$\alpha$-Bisabolol & 1653 & - & $3.1 \pm 0.2$ & - & - & - & - & - \\
\hline Others & & - & 10.5 & - & 1.6 & 19.3 & 1.8 & 2.4 \\
\hline Nonane & 899 & - & $1.1 \pm 0.2$ & - & $1.6 \pm 0.2$ & - & - & - \\
\hline Decane & 999 & - & $0.5 \pm 0.1$ & - & - & - & - & - \\
\hline Dodecane & 1199 & - & $1.0 \pm 0.2$ & - & - & $2.1 \pm 0.1$ & - & - \\
\hline Tetradecane & 1399 & - & $6.3 \pm 0.4$ & - & - & $17.5 \pm 1.3$ & $1.8 \pm 0.1$ & $2.4 \pm 0.4$ \\
\hline Hexadecane & 1599 & - & $1.6 \pm 0.3$ & - & - & $1.8 \pm 0.1$ & - & - \\
\hline Total & & 97.0 & 95.1 & 92.5 & 95.5 & 92.3 & 98.2 & 97.4 \\
\hline Yields (\%) & & $0.4 \pm 0.0$ & $0.04 \pm 0.0$ & $0.3 \pm 0.1$ & $0.6 \pm 0.1$ & $0.2 \pm 0.0$ & $0.7 \pm 0.1$ & $0.3 \pm 0.1$ \\
\hline
\end{tabular}

${ }^{a}$ Retention index relative to $\mathrm{C}_{9}-\mathrm{C}_{27} n$-alkanes on a DB-5 column. 
from the leaves of the same species. Among the sesquiterpenes, the oxygenated ones presented low concentrations, slightly higher for the oils from A. virgata, L. brasiliensis and L. montevidensis. The major constituents for all species were the sesquiterpenes $(E)$-caryophyllene (10-35\%), germacrene-D (5-46\%) and bicyclogermacrene (7-17\%).

Although the Lippia genus has been investigated, this work is the first report on the chemical composition of volatile oils from $L$. brasiliensis and L. sericea. For the species L. brasiliensis, due to its availability during the year, samples were collected during one year and it was observed that the oil composition varied slightly with the seasons (Table 2). There were no significant differences in the contents of major constituents; however, in the cold and dry months (May-September), there was increase in the oxygenated compounds concentrations. Similar results were found by Barros et al. ${ }^{23}$ for the species L. alba grown in São Luiz Gonzaga city, RS, Brazil. An increase in the content of oxygenated monoterpenes and sesquiter- pene during autumn (April) and winter (July) was observed. The phenotypic variations of morphology and volatiles production have been demonstrated to plants of Lippia genus in response to seasonal, ${ }^{23}$ phenological ${ }^{24}$ and soil ${ }^{25}$ variations.

According to Tavares et al..$^{24}$ the contents and composition of essential oil from L. alba varied within the phenological cycle, with higher oil production outside the flowering period. Barros et al. ${ }^{23}$ reported that during the spring, when the plants are flowering, greatest chemical diversity in the volatile oils from $L$. alba is observed. In this work, the L. brasiliensis flowering period occurred during the winter (July) (Table 2). For the oils extracted from the leaves at this time, there was no increase in the number of constituents. However, the oil extracted from the inflorescences revealed a higher variety of compounds, mainly with the presence of monoterpenes.

Higher concentrations of monoterpenes can also be observed for the oils from L. camara and L. trifolia flowers. In general, it is obser-

Table 2. Constituents and yields of essential oils (\%) from species Lippia brasiliensis

\begin{tabular}{|c|c|c|c|c|c|c|c|c|}
\hline \multirow[t]{2}{*}{ Constituents } & \multirow[t]{2}{*}{$\mathrm{RI}^{\mathrm{a}}$} & \multirow{2}{*}{$\begin{array}{l}\text { March } \\
\text { Leaves }\end{array}$} & \multirow{2}{*}{ May } & \multicolumn{2}{|c|}{ July } & \multirow{2}{*}{$\frac{\text { September }}{\text { Leaves }}$} & \multirow{2}{*}{$\begin{array}{c}\text { November } \\
\text { Leaves }\end{array}$} & \multirow{2}{*}{$\begin{array}{c}\text { January } \\
\text { Leaves }\end{array}$} \\
\hline & & & & Leaves & Flowers & & & \\
\hline Hydrocarbon Monoterpenes & & 2.8 & - & - & 9.9 & - & 2.6 & 6.1 \\
\hline$\alpha$-Pinene & 939 & - & - & - & $3.1 \pm 0.0$ & - & - & - \\
\hline Sabinene & 976 & $1.4 \pm 0.1$ & - & - & $2.6 \pm 0.1$ & - & $1.7 \pm 0.1$ & $4.1 \pm 0.2$ \\
\hline Limonene & 1031 & $1.4 \pm 0.0$ & - & - & $4.2 \pm 0.1$ & - & $0.9 \pm 0.0$ & $2.0 \pm 0.1$ \\
\hline Oxygenated Monoterpenes & & - & - & - & 5.8 & - & - & - \\
\hline Linalol & 1098 & - & - & - & $3.4 \pm 0.2$ & - & - & - \\
\hline Terpinen-4-ol & 1177 & - & - & - & $2.4 \pm 0.1$ & - & - & - \\
\hline Hydrocarbons Sesquiterpenes & & 84.5 & 82.7 & 78.7 & 59.2 & 81.0 & 82.8 & 82.0 \\
\hline$\delta$-Elemene & 1339 & $4.8 \pm 0.1$ & $4.9 \pm 0.1$ & $3.6 \pm 0.0$ & $2.0 \pm 0.0$ & $5.3 \pm 0.1$ & $4.6 \pm 0.2$ & $4.1 \pm 0.1$ \\
\hline$\alpha$-Cubebene & 1351 & $2.5 \pm 0.1$ & $1.1 \pm 0.0$ & $1.4 \pm 0.0$ & $0.8 \pm 0.0$ & $1.1 \pm 0.1$ & $1.1 \pm 0.1$ & $0.9 \pm 0.0$ \\
\hline$\alpha$-Copaene & 1376 & $5.9 \pm 0.1$ & $2.1 \pm 0.1$ & $2.7 \pm 0.1$ & $1.3 \pm 0.0$ & $2.3 \pm 0.2$ & $2.3 \pm 0.2$ & $1.8 \pm 0.1$ \\
\hline$\beta$-Bourbonene & 1384 & - & $0.5 \pm 0.0$ & $0.5 \pm 0.0$ & - & $0.7 \pm 0.0$ & $0.8 \pm 0.0$ & $1.4 \pm 0.1$ \\
\hline$\beta$-Cubebene & 1390 & $3.2 \pm 0.1$ & $1.6 \pm 0.1$ & $1.7 \pm 0.1$ & $0.8 \pm 0.0$ & $1.8 \pm 0.1$ & $1.8 \pm 0.1$ & - \\
\hline$\beta$-Elemene & 1391 & - & $0.6 \pm 0.0$ & $0.8 \pm 0.0$ & $1.1 \pm 0.0$ & $0.5 \pm 0.0$ & $0.7 \pm 0.0$ & $0.7 \pm 0.0$ \\
\hline$\alpha$-Gurjunene & 1409 & $1.1 \pm 0.0$ & $0.4 \pm 0.0$ & $0.7 \pm 0.0$ & - & $0.5 \pm 0.0$ & $0.6 \pm 0.0$ & $0.4 \pm 0.0$ \\
\hline (E)-Caryophyllene & 1418 & $33.2 \pm 1.8$ & $31.4 \pm 2.2$ & $30.7 \pm 1.3$ & $24.3 \pm 2.1$ & $29.1 \pm 2.4$ & $34.4 \pm 2.1$ & $35.6 \pm 1.8$ \\
\hline$\alpha$-Humulene & 1454 & $2.0 \pm 0.1$ & $2.7 \pm 0.1$ & $2.8 \pm 0.1$ & $2.5 \pm 0.1$ & $2.8 \pm 0.2$ & $2.4 \pm 0.1$ & $2.8 \pm 0.2$ \\
\hline Alloaromadendrene & 1461 & $2.4 \pm 0.1$ & $1.8 \pm 0.0$ & $1.7 \pm 0.1$ & $1.2 \pm 0.1$ & $1.7 \pm 0.1$ & - & $1.6 \pm 0.1$ \\
\hline Germacrene-D & 1480 & $16.4 \pm 0.8$ & $15.5 \pm 0.9$ & $13.9 \pm 0.8$ & $11.9 \pm 0.6$ & $16.1 \pm 0.9$ & $16.5 \pm 0.7$ & $19.3 \pm 0.9$ \\
\hline Bicyclogermacrene & 1494 & $2.0 \pm 0.1$ & $6.8 \pm 0.1$ & $4.2 \pm 0.1$ & $3.2 \pm 0.1$ & $7.1 \pm 0.4$ & $4.1 \pm 0.1$ & $2.4 \pm 0.1$ \\
\hline$\alpha$-Muurolene & 1499 & $2.8 \pm 0.1$ & $1.6 \pm 0.1$ & $0.5 \pm 0.0$ & - & $0.5 \pm 0.0$ & $1.1 \pm 0.1$ & $1.8 \pm 0.1$ \\
\hline$\alpha$-Farnesene & & - & $0.3 \pm 0.0$ & - & - & - & $0.2 \pm 0.0$ & $0.2 \pm 0.0$ \\
\hline$\gamma$-Cadinene & 1513 & $0.8 \pm 0.0$ & $1.1 \pm 0.0$ & $1.1 \pm 0.0$ & $0.5 \pm 0.0$ & $1.1 \pm 0.2$ & $1.0 \pm 0.0$ & $0.7 \pm 0.0$ \\
\hline (Z)-Calamenene & 1521 & $4.3 \pm 0.1$ & $4.0 \pm 0.1$ & $6.1 \pm 0.1$ & $5.6 \pm 0.1$ & $3.4 \pm 0.3$ & $4.3 \pm 0.3$ & $4.1 \pm 0.3$ \\
\hline$\delta$-Cadinene & 1524 & - & $1.1 \pm 0.1$ & $1.0 \pm 0.0$ & - & $1.0 \pm 0.1$ & $1.5 \pm 0.1$ & $1.0 \pm 0.1$ \\
\hline $\begin{array}{l}\text { 4-isopropyl-1,6-dimethyl-1,2,3,4,4a,7- } \\
\text { hexahydronaphthalene }\end{array}$ & 1532 & $3.1 \pm 0.1$ & $4.2 \pm 0.1$ & $4.1 \pm 0.1$ & $3.1 \pm 0.1$ & $5.0 \pm 0.3$ & $4.3 \pm 0.2$ & $3.2 \pm 0.2$ \\
\hline Germacrene-B & 1556 & - & $1.0 \pm 0.0$ & $1.2 \pm 0.1$ & $0.9 \pm 0.0$ & $1.0 \pm 0.1$ & $1.1 \pm 0.1$ & - \\
\hline Oxygenated Sesquiterpenes & & 3.5 & 8.6 & 13.6 & 12.0 & 7.3 & 4.4 & 4.3 \\
\hline Caryophyllene oxide & 1581 & $1.4 \pm 0.1$ & $1.3 \pm 0.1$ & $1.2 \pm 0.0$ & $0.9 \pm 0.0$ & $1.1 \pm 0.0$ & $1.4 \pm 0.2$ & $1.3 \pm 0.1$ \\
\hline Viridiflorol & 1590 & $0.9 \pm 0.0$ & $1.1 \pm 0.0$ & $2.6 \pm 0.1$ & $2.1 \pm 0.1$ & $1.4 \pm 0.1$ & $1.1 \pm 0.0$ & $1.3 \pm 0.0$ \\
\hline$\alpha$-Muurolol & 1645 & $0.6 \pm 0.0$ & $2.5 \pm 0.1$ & $3.9 \pm 0.1$ & $3.4 \pm 0.2$ & $2.2 \pm 0.2$ & $1.1 \pm 0.1$ & $1.1 \pm 0.1$ \\
\hline$\alpha$-Cadinol & 1653 & $0.6 \pm 0.0$ & $3.7 \pm 0.1$ & $5.9 \pm 0.4$ & $5.6 \pm 0.3$ & $2.6 \pm 0.1$ & $0.8 \pm 0.0$ & $0.6 \pm 0.0$ \\
\hline Others & & 6.8 & 7.5 & 5.8 & 9.5 & 7.2 & 7.7 & 5.9 \\
\hline oct-1-en-3-ol & 978 & - & - & - & $2.1 \pm 0.1$ & - & - & - \\
\hline $\mathrm{ni}^{\mathrm{b}}$ & 1454 & $6.8 \pm 0.2$ & $7.5 \pm 0.5$ & $5.8 \pm 0.2$ & $7.4 \pm 0.3$ & $7.2 \pm 0.6$ & $7.7 \pm 0.3$ & $5.9 \pm 0.4$ \\
\hline Total & & 97.6 & 98.8 & 98.1 & 96.4 & 95.5 & 97.5 & 98.3 \\
\hline Yields (\%) & & $0.4 \pm 0.0$ & $0.5 \pm 0.1$ & $0.3 \pm 0.1$ & $0.7 \pm 0.1$ & $0.5 \pm 0.1$ & $0.3 \pm 0.0$ & $0.4 \pm 0.1$ \\
\hline
\end{tabular}

${ }^{\text {a }}$ Retention index relative to $\mathrm{C}_{9}-\mathrm{C}_{27} n$-alkanes on a DB-5 column. ${ }^{\mathrm{b}}$ Not identified. 
ved that floral volatiles serve as attractions for specific pollinators, whereas the volatiles emitted by vegetative parts, appear to protect plants by deterring the herbivores from attacking. ${ }^{26}$

Therefore, the different composition of essential oils from flowers of these species may be associated to certain ecological interactions, such as attracting species-specific pollinators.

(E)-Caryophyllene has been commonly used as a fragrance chemical since the $1930 \mathrm{~s} .{ }^{27}$ It is used in spice blends, citrus flavors, soaps, detergents, creams and lotions, and in a variety of food products and beverages. (E)-Caryophyllene is also known for its anti-inflammatory and local anesthetic properties. ${ }^{28}$ Recently, Gertsch et al. ${ }^{29}$ showed that this compound selectively binds to the cannabinoid receptor type 2 (CB2), but not to type 1 (CB1), leading to cellular activation and anti-inflammatory effects. Although the $\mathrm{CB} 1$ receptor is responsible for the psychomodulatory effects of cannabinoids agonists, activation of the $\mathrm{CB} 2$ receptor is a potential therapeutic strategy for the treatment of inflammation, pain, atherosclerosis, and osteoporosis. Since the essential oils constituents, such as $(E)$-caryophyllene and germacrene-D can be purified, ${ }^{30}$ the investigated plants become potential alternative sources of these important bioactive compounds.

\section{Antibacterial activity}

The evaluation of antibacterial activity by the Agar disc diffusion method showed that the volatile oils isolated from L brasiliensis, A. virgata, L. camara, L. montevidensis and L. trifolia have different activity levels against each bacterial strain (Table 3 ). The quantity available of Lippia sericea was reduced and it did not produce enough oil for the bioassays.

Table 3. Diameter of the inhibition zones of bacterial growth for the essential oils from leaves of the species Lippia brasiliensis, Aloysia virgata, Lantana camara, L. trifolia and L. montevidensis and the minimum inhibitory concentration (MIC) of bacterial growth for the essential oils extracted from leaves of the species Lippia brasiliensis and Aloysia virgata

\begin{tabular}{lccc}
\hline \multirow{2}{*}{ Essential Oils } & \multicolumn{3}{c}{ Inhibition zones diameter $(\mathrm{mm})^{\mathrm{a}}$} \\
\cline { 2 - 4 } & $\mathrm{G}(-)$ & \multicolumn{2}{c}{$\mathrm{G}(+)$} \\
\cline { 2 - 4 } Lippia brasiliensis & $6 \mathrm{C} \mathrm{coli}$ & B. cereus & S. aureus \\
Aloysia virgata & $11 \mathrm{~B} \mathrm{~b}$ & $16 \mathrm{~A} \mathrm{~b}$ & $15 \mathrm{~B} \mathrm{~b}$ \\
Lantana camara & $6 \mathrm{~A} \mathrm{c}$ & $8 \mathrm{~A} \mathrm{~d}$ & $16 \mathrm{~A} \mathrm{~b}$ \\
Lantana trifolia & $6 \mathrm{C} \mathrm{c}$ & $13 \mathrm{~A} \mathrm{c}$ & $10 \mathrm{~B} \mathrm{c}$ \\
Lantana montevidensis & $6 \mathrm{C} \mathrm{c}$ & $18 \mathrm{~A} \mathrm{~b}$ & $13 \mathrm{~B} \mathrm{~b}$ \\
\hline Control $\left(\mathrm{H}_{2} \mathrm{O}\right)$ & $6 \mathrm{~A} \mathrm{c}$ & $6 \mathrm{~A} \mathrm{~d}$ & $6 \mathrm{~A} \mathrm{~d}$ \\
Chloramphenicol $30 \mu \mathrm{g}$ & $29 \mathrm{~B} \mathrm{a}$ & $29 \mathrm{~B} \mathrm{a}$ & $32 \mathrm{~A} \mathrm{a}$ \\
\hline Essential Oils & Minimum inhibitory concentration $(\% \mathrm{v} / \mathrm{v})$ \\
\hline Lippia brasiliensis & 0.5 & 0.125 & 0.125 \\
Aloysia virgata & 0.125 & 0.125 & 0.125 \\
\hline
\end{tabular}

${ }^{a}$ Means followed by same capital letter in the lines and small letter in the columns are not different for the Scott-Knott's test at $\mathrm{P} \leq 0.05$.

The oils of all tested species, except $L$. camara, showed moderate activity against Gram-positive bacteria (B. cereus and S. aureus). Only the oil isolated from A. virgata was active against Gram-negative E. coli.

Deena and Thoppil ${ }^{31}$ observed antibacterial activity to the essential oils from L. camara collected in Calicut, India. The major compounds found by these authors were $(E)$-caryophyllene $(35 \%)$, geranyl acetate $(22 \%)$, terpenyl acetate $(6 \%)$ and bornyl acetate
(4\%). In our work, the absence of these oxygenated compounds in L. camara oil may be co-related to the lack of antibacterial activity for the plant from Brazil.

From the leaves of L. trifolia were isolated umuhengerin, a pentamethoxyflavone with antibacterial and antifungal activities. ${ }^{32}$ More recently, it has been reported anti-inflammatory and antinociceptive activities of non-polar extracts from the leaves of L. trifolia. ${ }^{33} \mathrm{Ho}-$ wever, no reports on biological activities of essential oils from this species were found in the literature. Our results indicate a low antibacterial activity for the volatile oils produced by L. trifolia against the tested bacterial strains.

Essential oils from L. achyranthifolia, mainly composed by carvacrol (31\%), -bisabolol (11\%) and 1,8-cineole (5\%), showed moderate antibacterial activity, with MIC values between 1.0 and $0.25 \mathrm{mg} \mathrm{L}^{-1} .^{34}$ Those substances have known antimicrobial activity. Additionally, it has been demonstrated that the presence of phenolic hydroxyl group in carvacrol is essential for its activity against B. cereus. ${ }^{35}$

The mechanism of action of essential oils from Melaleuca alternifolia (Myrtaceae) (tea tree oil - TTO) against the bacteria E. coli and $S$. aureus, and the yeast Candida albicans has been investigated. It has been shown that the main effects on bacteria and yeast were respiration inhibition and increase of cell membrane permeability. The disruption of cell membrane integrity leads to a $\mathrm{K}^{+}$ion leakage and consequent loss of chemiosmotic cell control. ${ }^{36}$ This mode of action is similar to that of others broad-spectrum membrane-active disinfectants and preservatives, such as phenol derivatives, chlorhexidine and parabenzoic acid derivatives. ${ }^{37}$

The MIC value obtained (Table 3 ) confirms that the oil from $L$. brasiliensis have very low activity against $E$. coli $(0.5 \%)$, whereas the oil from A. virgata inhibit the growth of this bacteria at the concentration of $0.125 \%$. The oils from both plants showed the same MIC values $(0.125 \%)$ against $B$. cereus and $S$. aureus.

Although the volatile oils obtained from this Verbenaceae have very similar composition, they showed different levels of activity against different bacterial strains. Some studies have shown that whole essential oils have greater antibacterial activity than the major components mixed. ${ }^{38}$ This suggests that the minor components are critical to the activity and may have a synergistic effect or potentiating influence. Besides, the mode of action of the essential oil seems depending on the bacterial strain. Furthermore, it is also noteworthy that synergistic and, or antagonistic effects might be taken into account for the activity observed in complex mixtures, such as essential oils.

\section{CONCLUSIONS}

In conclusion, the essential oils from A. virgata, L. brasiliensis, L. sericea, L. camara, L. montevidensis and L. trifolia, collected in Minas Gerais, Brazil, are chemically similar, and this species are potential alternative source of $(E)$-caryophyllene and germacrene-D. The results described also demonstrate the promising possibility of using of the essential oils from A. virgata, L. brasiliensis, L. montevidensis and $L$. trifolia as an alternative to some disinfectants and preservatives against Gram-positive and Gram-negative bacteria.

\section{ACKNOWLEDGEMENTS}

The authors are grateful the Conselho Nacional de Desenvolvimento Científico e Tecnológico $(\mathrm{CNPq})$ and Fundação de Amparo à Pesquisa do Estado de Minas Gerais (FAPEMIG) for financial support and research fellowships (L. C. A. Barbosa and A. J. Demuner). We are also grateful to Dr. A. Rathi (Department of Chemistry, Oxford University, UK) for suggestions and corrections on the manuscript. We also thank Prof. R. Meira (UFV) for collecting a sample of Lippia sericea. 


\section{REFERENCES}

1. Giulietti, A. M.; Menezes, N. L.; Pirani, J. R.; Meguro, M.; Wanderley, M. L.; Bol. Bot. Univ. 1987, 9, 1.

2. Cavalcanti, S. C. H.; Niculau, E. S.; Blank, A. F.; Câmara, C. A. G.; Araújo, I. N.; Alves, P. B.; Bioresour. Technol. 2010, 101, 829.

3. Bassole, I. H. N.; Ouattara, A. S.; Nebie, R.; Ouattara C. A. T.; Kabore, Z. I.; Traore, A. S.; Phytochemistry 2003, 62, 209.

4. Manenzhe, N. J.; Potgieter, N.; Ree, R.; Phytochemistry 2004, 65, 2333.

5. Tadeg, H.; Mohammed, E.; Asres, K.; Gebre-Mariam, T.; J. Ethnopharmacol. 2005, 100, 168.

6. Duarte, M. C. T.; Figueira, G. M.; Sartoratto, A.; Rehder, V. L. G.; Delarmelina, C.; J. Ethnopharmacol. 2005, 97, 305.

7. Pino, J. A.; Marbot, R.; Fuentes, V.; J. Essent. Oil Res. 2004, 16, 44.

8. Ricciardi, G. A. L.; Torres, A. M.; Baren, C. V.; Lira, P. D. L.; Ricciardi, A. I. A.; Dellacassa, E.; Lorenzo, D.; Bandoni, A. L.; Flav. Frag. J. 2005, 20,645.

9. Padalia, R. C.; Verma, R. S.; Sundaresan, V.; Rec. Nat. Prod. 2010, 4, 109; Costa, J. G. M.; Sousa, E. O.; Rodrigues, F. F. G.; Lima, S. G.; Braz-Filho, R.; Braz. J. Pharmacogn. 2009, 19, 710; Oliveira, J. C. S.; Neves, I. A.; Camara, C. A. G.; Schwartz, M. O. E.; J. Essent. Oil. Res. 2008, 20,530 .

10. Sousa, E. O.; Rodrigues, F. F. G.; Coutinho, H. D. M.; Campos, A. R.; Lima, S. G.; Costa, F. G. M.; Rec. Nat. Prod. 2011, 5, 60.

11. Gottlieb, O. R.; Kaplan, M. A. C.; Borin, M. R. M. B.; Biodiversidade um enfoque químico-biológico, Editora da UFRJ: Rio de Janeiro, 1996.

12. Viccini, L. F.; Pierre, P. M. O.; Praça, M. M.; Costa, D. C. S.; Romanel, E. C.; Sousa, S. M.; Peixoto, P. H. P.; Salimena, F. R. G.; Plant Syst. Evol. 2006, 256, 171; Silva, C. J.; Barbosa, L. C. A.; Demuner, A. J.; Montanari, R. M.; Pinheiro, A. L.; Dias, I.; Andrade, N. J.; Quim. Nova 2010, 33, 104.

13. Barbosa, L. C. A.; Paula, V. F.; Azevedo, A. S.; Silva, E. M. M.; Nascimento, E. A.; Flav. Fragr. J. 2005, 20, 39; Fonseca, M. C. M.; Barbosa, L. C. A.; Nascimento, E. A.; Casali, V. W. D.; J. Essent. Oil Res. 2006, 18, 345; Martins, F. T.; Santos, M. H.; Pólo, M.; Barbosa, L. C. A.; Quim. Nova 2006, 29, 1203; Barbosa, F. F.; Barbosa, L. C. A.; Melo, E. C.; Botelho, F. M.; Santos, R. H. S.; Quim. Nova 2006, 29, 122; Martins, F. T.; Dorigueto, A. C.; Souza, T. C.; Souza, K. R. D.; Santos, M. H.; Moreira, M. E. C.; Barbosa, L. C. A.; Chem. Biodivers 2008, $5,251$.

14. Adams R. P.; Identification of essential oil components by gas chromatography/mass spectroscopy, Allured Publishing Corporation: Illinois, 1995.

15. Salustiano, V. C.; Andrade, N. J.; Soares, N. F. F.; Lima, J. C.; Bernardes, P. C.; Luiz, L. M. P.; Fernandes, P. E.; Food Control 2009, 20,439 .
16. National Committee for Clinical Laboratory Standards; Performance standards for antimicrobial susceptibility test. Ninth International Supplement, M100-S9, NCCLS: Wayne, 1997.

17. National Committee for Clinical Laboratory Standards; Performance standards for antimicrobial susceptibility test. Ninth International Supplement. M100-S9, Wayne, PA. 1999.

18. Bülow, N.; König, W. A.; Phytochemistry 2000, 55, 141.

19. Degenhardt, J.; Köllner, T. G.; Gershenzon, J.; Phytochemistry 2009, 70, 1621; Barbosa, L. C. A.; Demuner, A. J.; Clemente, A. D.; Paula, V. F.; Ismail, F. M. D.; Quim. Nova 2007, 30, 1959.

20. Ghisalberti, E. L.; Fitoterapia 2000, 71, 467.

21. Silva, M. H. L.; Andrade, E. H. A.; Zoghbi, M. G. B.; Luz, A. I. R.; Silva, J. D.; Maia, J. G. S.; Flav. Fragr. J. 1999, 14, 208.

22. Muhayimana, A.; Chalchat, J. C.; Garry, R. P.; J. Essent. Oil Res. 1998, 10, 547.

23. Barros, F. M. C.; Zambarda, E. O.; Heinzmann, B. M.; Mallmann, C. A.; Quim. Nova 2009, 32, 861.

24. Tavares, E. S.; Julião, L. S.; Lopes, D.; Bizzo, H. R.; Lage, C. L. S.; Leitão, S. G.; Rev. Bras. Farmacogn. 2005, 15, 1.

25. Montanari, R. M.; Sousa, L. A.; Leite, M. N.; Coelho, A. D. F.; Viccini, L. F.; Stefanini, M. B.; Rev. Bras. Pl. Med. 2004, 6, 96.

26. Pichersky, E.; Gershenzon, J.; Curr. Opin. Plant Biol. 2002, 5, 237.

27. Opdyke, D. L. J.; Food and Cosmetics Toxicol. 1973, 11, 1059.

28. Ghelardini, C.; Galeotti, N.; Di Cesare, M. L.; Mazzanti, G.; Bartolini, A.; Il Farmaco 2001, 56, 387.

29. Gertsch, J.; Leonti, M.; Raduner, S.; Racz, I.; Chen, J. Z.; Xie, C. Q.; Altmann, K. H.; Karsak, M.; Zimmer, A.; Proc. Natl. Acad. Sci. U. S. A. 2008, 105, 9099.

30. Brochini, C. B.; Núñez, C. V.; Moreira, I. C.; Roque, N. F.; Chaves, M. H.; Martins, D.; Quim. Nova 1999, 22, 37.

31. Deena, M. J.; Thoppil, J. E.; Fitoterapia 2000, 71, 453.

32. Rwangabo, P. C.; Claeys, M.; Pieters, L.; Corthout, J.; Vanden-Berghe, D. A.; Vlietinck, A. J.; J. Nat. Prod. 1988, 51, 966.

33. Silva, G. N.; Martins, F. R.; Matheus, M. E.; Leitão, S. G.; Fernandes, P. D.; J. Ethnopharmacol. 2005, 100, 254.

34. Hernández, T.; Canales, M.; Avila, J. G.; García, A. M.; Martínez, A.; Caballero, J.; Vivar, A. R.; Lira, R.; J. Ethnopharmacol. 2005, 96, 551.

35. Ultee, A.; Bennik, M. H. J.; Moezelaar, R.; Appl. Environ. Microbiol. 2002, 68, 1561

36. Cox, S. D.; Mann, C. M.; Karkham, J. L.; Bell, H. C.; Gustafson, J. E.; Warmington, J. R.; Wyllie, S. G.; J. Appl. Microbiol. 2000, 88, 170.

37. McDonnell, G.; Russell, A. D.; Clinical Microbiol. Rev. 1999, $12,147$.

38. Al-Bayat, F. A.; J. Ethnopharmacol. 2008, 116, 403. 